\title{
Nutritional composition of Synodontis nigrita and Tilapia mariae from the Jamieson River, Sapele, Delta State, Nigeria
}

\author{
Ijeoma Patience Oboh*, \\ Oluwatosin Adesola Sanni, \\ Nkonyeasua Kingsley Egun \\ Department of Animal \\ and Environmental Biology, \\ University of Benin, \\ P.M.B. 1154 Ugbowo, \\ Benin City, Edo State, Nigeria
}

\begin{abstract}
The proximate composition of fish is important for easy formulation of both animal and human diets. The study on the proximate and mineral composition of captured Synodontis nigrita and Tilapia mariae was aimed at gaining knowledge of their consumption-associated benefits. Fish specimens were purchased on the bank of the river between February and April 2017 and transported to the laboratory where routine measurements, body and biochemical analysis for moisture content, fat, ash, protein, crude fibre, carbohydrate, sodium, potassium, calcium, and magnesium were performed using the standard methods of AOAC. The result of the proximate composition of Synodontis nigrita and Tilapia mariae showed moisture content of $79.00 \%$ and $78.87 \%$, fat value of $3.43 \%$ and $0.67 \%$, ash content of $6.22 \%$ and $6.68 \%$, protein value of $7.09 \%$ and $8.84 \%$, crude fibre value of $0.40 \%$ and $1.80 \%$, carbohydrate content of $3.86 \%$ and $3.14 \%$, respectively. The mineral composition of Synodontis nigrita and Tilapia mariae revealed sodium values of $32.90 \mathrm{mg} / \mathrm{kg}$ and $30.20 \mathrm{mg} / \mathrm{kg}$, potassium values of $171.70 \mathrm{mg} / \mathrm{kg}$ and $175.60 \mathrm{mg} / \mathrm{kg}$, calcium values of $13.50 \mathrm{mg} / \mathrm{kg}$ and $9.20 \mathrm{mg} / \mathrm{kg}$, magnesium content of $15.00 \mathrm{mg} / \mathrm{kg}$ and $13.40 \mathrm{mg} / \mathrm{kg}$, respectively. The results obtained in this study provided scientific knowledge of the nutritional composition of these commercial fish species.
\end{abstract}

Keywords: Proximate composition, mineral content, Synodontis nigrita, Tilapia mariae, Jamieson River

\section{INTRODUCTION}

Fish is an essential resource to humans globally as its production plays an important role in nutrition and contributes to food security, especially in many developing countries where reliable access to nutritious food is on the decline. Fish is one of

\footnotetext{
*Corresponding author. Email:obohij@yahoo.com
}

the healthiest and inexpensive sources of animal protein and other important nutrients required in human diets in Africa (Amiengheme, 2005; Sadiku, Oladimeji, 1991). It has a lot of food potential and can therefore be expected to provide relief from malnutrition, especially in the developing countries (Adeniyi et al., 2012; Ashraf et al., 2011). In Nigeria, the demand for fish in the market has risen due to an increase in the population's awareness of the nutritional value of fish. 
Information on the chemical composition of fish is vital as the nutritional and medicinal value of fish products depends on its proteins, lipids, minerals, and vitamins. The knowledge of such fish constituents as moisture, crude protein, ash, lipids, carbohydrates, amino acids and minerals, and factors affecting them allow for the assessment of fish health status and the quality of the nutrients available to the consumer (Shearer, 1994). Proximate composition is the analysis of moisture, fat, protein and ash content of fish. It is used as an indicator of fish quality and it varies with diet, feeding rate, age, and genetic strain (Love, 1980; Adewumi et al., 2015). The most important mineral elements in fish are potassium, calcium, sodium, iron, phosphorous, and chlorine, while other mineral elements are needed in trace amounts (Mills, 1980; Womeni et al., 2014; Salma, Nizar, 2015).

The Jamieson River is rich in commercially important fish species such as Arius gigas, Synodontis nigrita, and Tilapia mariae. Although several biological studies have been carried out on various aspects of these fish species in the Jamieson River, investigations on their proximate and mineral composition are limited. Therefore, the aim of this study was to determine the proximate and mineral composition of Synodontis nigrita and Tilapia mariae from the Jamieson River, Sapele, Delta state.

\section{MATERIALS AND METHODS}

Study area. This study was carried out in the Jamieson River that is located in the NigerDelta region of Nigeria. The Jamieson River is a tributary of the Benin River and lies between $5^{\circ} 41^{\prime}$ to $5^{\circ} 58^{\prime \prime} \mathrm{E}$ and $5^{\circ} 54^{\prime}$ to $6^{\circ} 08^{\prime \prime} \mathrm{N}$.

Fish collection and identification. Selected fish species for this study were Synodontis nigrita and Tilapia mariae. Synodontis nigrita (Curvier, Valenciennes, 1840) and Tilapia mariae (Boulenger, 1899) belong to the family Mochokidae and Cichlidae. The genus Synodontis is the largest genus of the catfish of the order $\mathrm{Si}$ luriformes and is most widely distributed (Friel, Vigliotta, 2006).
Fish samples were procured fresh from landing sites at the Jamieson River. A total of 54 fish specimens consisting of 27 specimens of Synodontis nigrita and 27 specimens of Tilapia mariae were collected over a period of three months, February to April 2017. The samples were preserved in ice blocks, transported to the laboratory, and properly identified using taxonomic guides of Idodo-Umeh (2003). Routine measurements of the standard length, the total length, and the body weight of all fish samples were taken to the nearest $0.1 \mathrm{~cm}$ and $0.1 \mathrm{~g}$ using a metre rule and digital electronic weighing balance Mettler Toledo, PL203 model, respectively. The fish samples were thoroughly washed with distilled water to remove any adhering contaminants and drained under folds of filter paper. The head and gut were also discarded and the samples were stored in a deep freezer prior to analysis.

Proximate analysis. The proximate composition (moisture, fat, ash, protein, crude fibre, and carbohydrate) and mineral content of Synodontis nigrita and Tilapia mariae were determined using the standard methods of the Association of Official Analytical Chemists (AOAC, 2010).

Data analysis. Statistical analyses were computed using Microsoft Excel and the Statistical Package for Social Sciences (SPSS 16.0). Analysis of variance (ANOVA) was used to test for significant difference $(p<0.01)$ between means, and the source of significant differences was identified using Duncan's Multiple Range (DMR) test.

\section{RESULTS AND DISCUSSION}

The results of the proximate and mineral composition of Synodontis nigrita and Tilapia mariae over the months are displayed in Tables 1 and 2. The total length of Synodontis nigrita ranged from $17.50 \mathrm{~cm}$ to $27.90 \mathrm{~cm}$, the standard length from $12.7 \mathrm{~cm}$ to $19.50 \mathrm{~cm}$, and the body weight from 31.30 to $209.08 \mathrm{~g}$. The total length of Tilapia mariae ranged from $12.50 \mathrm{~cm}$ to $21.00 \mathrm{~cm}$, the standard length from 10.20 to $17.80 \mathrm{~cm}$, and the body weight from $41.29 \mathrm{~g}$ to $233.12 \mathrm{~g}$. 
Table 1. Summary of the proximate composition of Synodontis nigrita and Tilapia mariae from the Jamieson River

\begin{tabular}{c|c|c|c|c|c|c|c}
\hline \multirow{2}{*}{ Proximate composition } & \multicolumn{3}{|c|}{ Synodontis nigrita } & \multicolumn{3}{c}{ Tilapia mariae } & \multirow{2}{*}{$p$-value } \\
\cline { 2 - 8 } & $\bar{X}+$ S D & Min & Max & $\bar{X}+$ S D & Min & Max & \\
\hline Moisture & $79.00 \pm 2.35^{\mathrm{c}}$ & 76.65 & 81.35 & $78.87 \pm 0.66^{\mathrm{c}}$ & 78.21 & 79.53 & $<0.01$ \\
\hline Fat & $3.43 \pm 0.46^{\mathrm{a}}$ & 2.97 & 3.89 & $0.67 \pm 0.04^{\mathrm{a}}$ & 0.63 & 0.71 & $<0.01$ \\
\hline Ash & $6.22 \pm 1.05^{\mathrm{b}}$ & 5.17 & 7.27 & $6.68 \pm 0.56^{\mathrm{b}}$ & 6.12 & 7.24 & $<0.01$ \\
\hline Protein & $7.09 \pm \pm 0.16^{\mathrm{a}}$ & 6.93 & 7.25 & $8.84 \pm 0.40^{\mathrm{a}}$ & 8.44 & 9.24 & $<0.01$ \\
\hline Crude Fibre & $0.40 \pm 0.02^{\mathrm{a}}$ & 0.38 & 0.42 & $1.80 \pm 0.20^{\mathrm{a}}$ & 1.60 & 2.00 & $<0.01$ \\
\hline Carbohydrate & $3.86 \pm 0.70^{\mathrm{a}}$ & 3.16 & 4.56 & $3.14 \pm 1.06^{\mathrm{a}}$ & 2.08 & 4.20 & $<0.01$ \\
\hline
\end{tabular}

Note: Similar letters (superscripts) indicate values that are not significantly different from each other $(p<0.01)$.

Table 2. Summary of the mineral composition of Synodontis nigrita and Tilapia mariae from the Jamieson River

\begin{tabular}{c|c|c|c|c|c|c|c}
\hline \multirow{2}{*}{ Mineral composition } & \multicolumn{3}{|c|}{ Synodontis nigrita } & \multicolumn{3}{c|}{ Tilapia mariae } & \multicolumn{2}{c}{$p$-value } \\
\cline { 2 - 8 } & $\bar{X}+$ S D & Min & Max & $\bar{X}+$ S D & Min & Max & \\
\hline Sodium & $32.90 \pm 0.40^{\mathrm{b}}$ & 32.50 & 33.30 & $30.20 \pm 2.90^{\mathrm{b}}$ & 27.30 & 33.10 & $<0.01$ \\
\hline Potassium & $171.70 \pm 0.50^{\mathrm{c}}$ & 171.20 & 172.20 & $175.60 \pm 9.10^{\mathrm{c}}$ & 166.50 & 184.70 & $<0.01$ \\
\hline Calcium & $13.50 \pm 0.60^{\mathrm{b}}$ & 12.90 & 14.10 & $9.20 \pm 0.60^{\mathrm{a}}$ & 8.60 & 9.80 & $<0.01$ \\
\hline Magnesium & $15.00 \pm 0.50^{\mathrm{c}}$ & 14.50 & 15.50 & $13.40 \pm 0.26^{\mathrm{b}}$ & 13.10 & 13.60 & $<0.01$ \\
\hline
\end{tabular}

Note: Similar letters (superscripts) indicate values that are not significantly different from each other $(p<0.01)$.

The moisture content of the muscles of fresh samples for Synodontis nigrita (79\%) and Tilapia mariae $(78.87 \%)$ were within acceptable levels of $60 \%$ to $80 \%$ (Gallagher et al., 1991). Similar high moisture content values were reported in fresh samples of T. guineensis (79.50\%) and T. melanotheron (79.50\%) by Adejonwo et al. (2010), and in Tilapia zilli (78.11\%) and Sarotherodon galilaeus (79.63\%) by Adewumi et al., (2014).

Fish lipids are rich in polyunsaturated fatty acid, particularly omega-3-fatty acids which have an important role in disease prevention and health promotion (Omotosho et al., 2011; Omoruyi et al., 2017). A comparison of the fat content of Synodontis nigrita with that of Tilapia mariae indicates that Synodontis nigrita has a higher fat content. Similar values were reported by Bombata-Fashina et al. (2013) for T. mariae (0.65\%) and by Omoruyi et al. (2017) for Synodontis clarias (2.73\%). Ackman (1989) stated that fish can be grouped into four categories according to their fat content: lean $(<2 \%)$, low fat ( 2 to $4 \%$ ), medium fat (4 to $8 \%$ ), and high fat $(>8 \%)$. Results obtained from this study showed that fresh samples of $S$. nigrita and $T$. mariae belong to the low fat and lean categories, respectively.

The ash content is a measure of the total amount of minerals present in a food. It is the inorganic residue that remains after the organic matter has been burnt off (Adewumi et al., 2014). The ash content was higher in fresh samples of T. mariae (6.68\%) than in those of S. nigrita (6.22\%). The observed range of the ash content in S. nigrita and T. mariae indicates that the species are a good source of such minerals as potassium, calcium, sodium, and magnesium. The difference in the ash content could be attributed to the fish species, season, sex, or food availability (Effiong, Mohammed, 2008).

Low protein content in fresh samples of S. nigrita (7.09\%) and T. mariae (8.84\%) was recorded. In contrast, high protein content values of $18.08 \%, 11.79 \%$, and $19.13 \%$ were reported 
in fresh samples of T. mariae (Bombata-Fashina et al., 2013), S. schall (Oyase et al., 2016), and S. clarias (Omoruyi et al., 2017), respectively. This could be attributed to variation in fish size, age, and seasonal variations.

Fish generally have very low levels of carbohydrates because glycogen does not contribute much to the reserves in the fish body tissue (Das and Sahu, 2001). The percentage of $1.80 \%$ of crude fibre content in fresh samples of T. mariae (1.80\%) was higher than that observed in fresh samples of S. nigrita (0.40\%). A higher crude fibre content for fresh samples of Synodontis nigrita (2.07\%) and Synodontis clarias $(2.10 \%)$ were reported by Ndome et al. (2010) and Omoruyi et al. (2017), respectively. A comparison of the carbohydrate content of S. nigrita and T. mariae indicate that $S$. nigrita has higher carbohydrate content. Ndome et al. (2010) and Salihu-Lasisi et al. (2013) reported similar values of $3.49 \%$ and $3.67 \%$ for fresh samples of $S$. nigrita and T. nilotica.

Although fish is very unlikely to be the only source of an essential mineral in human diet, it provides a well-balanced supply of minerals in a readily usable form (Ako, Salihu, 2004). Sodium participates in acid-base balance and isotonicity and plays an important role in the metabolic and neuromuscular systems. The richness in sodium $\left(\mathrm{Na}^{+}\right)$concentrations boosts the osmoregulatory activities in organisms (Bentley, 1971). The concentration of sodium in fresh samples of Synodontis nigrita $(32.90 \mathrm{mg} / \mathrm{kg})$ was higher than in fresh samples of Tilapia mariae $(30.20 \mathrm{mg} / \mathrm{kg})$. The concentration of sodium in fresh samples of $S$. nigrita and T. mariae could be attributed to the concentration of sodium in the water body or the capacity of the fish to absorb the elements from their diets and the water bodies.

Overall results showed that potassium was the most abundant element in both fish species when compared to all minerals analysed. A similar trend was reported in T. guineensis by Adeniyi et al. (2012). The highest potassium content $(175.60 \mathrm{mg} / \mathrm{kg})$ was recorded in T. mariae. In contrast, Adeniyi et al. (2012) reported low potassium content in fresh samples of Tilapia guineensis $(91.51 \mathrm{mg} / \mathrm{kg})$. Potassium is involved in protein synthesis, nerve conduction, regulation of the blood pressure; in addition, it contributes to the maintenance of the intracellular osmotic pressure (Soetan et al., 2010).

S. nigrita had a higher calcium content of $13.50 \mathrm{mg} / \mathrm{kg}$ than the value of $9.20 \mathrm{mg} / \mathrm{kg}$ recorded in T. mariae. Higher calcium content in fresh samples of S. nigrita over T. mariae can be attributed to its benthic nature and its relative preference for consumption of fish scales, crustaceans, insect parts, and larvae. Fresh samples of $S$. nigrita had higher magnesium content (15.00 mg/kg) than T. mariae $(13.40 \mathrm{mg} / \mathrm{kg})$. In contrast, Adeniyi et al. (2012) reported high magnesium content of $41.44 \mathrm{mg} / \mathrm{kg}$ in fresh samples of T. guineensis.

\section{CONCLUSIONS}

A large percentage of consumers eat fish because of its flavour, availability, and palatability, and a smaller percentage eat fish because of its nutritional value. This study shows that $S$. nigrita does not exceed T. mariae in nutritional quality. Although $S$. nigrita has a higher content of calcium and magnesium, both fish species are of a high nutritional value and a good source of minerals, and therefore are highly recommended for consumption.

Received 23 November 2018

Accepted 9 April 2019

\section{References}

1. Ackman RG. Nutritional composition of fats in sea foods. Prog Food Nutr Sci. 1989; 13(34): 161-241.

2. Adejonwo OA, Kolade OY, Ibrahim AO, Oramadike CE, Ozor PA. Proximate and anatomical weight composition of wild brackish Tilapia guineensis and Tilapia melanotheron. Internet J Food Saf. 2010; 12: 100-3.

3. Adeniyi SA, Orjiekwe CL, Ehiagbonare JE, Josiah SJ. Nutritional composition of three 
different fishes (Clarias gariepinus, Malapterurus electricus and Tilapia guineensis). Pak J Nutr. 2012; 11(9): 891-5.

4. Adewumi AA, Adewole HA, Olaleye VF. Proximate and elemental composition of the fillets of some fish species in Osinmo Reservoir, Nigeria. ABJNA. 2014; 5(3): 109-17.

5. Adewumi AA, Ogunlade I, Coker FF. Effect of processing on the nutritive value of Clarias gariepinus from Isinla Fish Pond, Ado Ekiti, Nigeria. AJBio. 2015; 3(6): 262-6.

6. Ako PA, Salihu SO. Studies on some major and trace metals in smoked and oven-dried fish. J App Sci Environ Manage. 2004; 8(2): 5-9.

7. Amiengheme P. The importance of fish in human nutrition: a paper delivered at a fish culture forum, Federal Department of Fish Farmers, Abuja, Nigeria; 2005. pp. 21.

8. Ashraf MA, Zafar A, Rauf A, Mehboob S, Qureshi NA. Nutritional values of wild and cultivated silver carp (Hypophthalmichthys molitrix) and grass carp (Ctenopharyngodon idella). Int J Agric Biol. 2005; 13: 210-4.

9. Austreng E, Refstie T. Effects of varying dietary protein level in different families of rainbow trout. Aquaculture. 1979; 18: 145-56.

10. Bentley PJ. Endocrine and osmoregulation. Heidelberg: Springer-Verlag; 1971. pp. 220-30.

11. Bombata-Fshina HA, Megbowon I, Okunade O, Ozor PA, Ibrahim AO, Adejonwo OA, Kolade OY. Comparative study of the proximate composition of some wild tilapiine fishes in Epe Lagoon, Lagos, Nigeria. J Fish Aquat Sci. 2013; 8(1): 265-7.

12. Boulenger GA. Catalogue of the freshwater fishes of Africa in the British museum (Natural history), London: British Museum. 1899; p. $429-30$.

13. Curvier G, Valenciennes A. Synodontis nigrita: Fisheries. 1840 [cited 2017 May 29]. Available from: http://www.fishbase.org/summary/ synodontis-nigrita.html.
14. Das S, Sahu BK. Biochemical composition and calorific content of fishes and shellfishes from Rushikulya Estuary, South Orissa Coast of India. Indian J Fish. 2001; 48: 297-302.

15. Effiong BN, Mohammed I. Effect of seasonal variation on the nutrient composition in selected fish species in lake Kainji Nigeria. Nature Science. 2008; 6(2): 1-5.

16. Friel JP, Vigliotta TR. Mochokidae Jordan 1923: African Squeaker and Suckermouth catfishes: Tree of Life Web Project, 2009[cited 2017 June 3]. Available from: http://tolweb. org/Mochokidae/15214.

17. Gallagher ML, Harrell ML, Rulifson RA. Variation in lipid and fatty acid contents of Atlantic croakers, striped mullet and summer flounder. T Am Fish Soc. 1991; 120(5): 614-9.

18. Idodo-Umeh G. Freshwater fisheries of Northern Nigeria - taxonomy, ecological notes, diet and utilization. 2003 ISBN 978-8052-01-0.

19. Love RM. 1980. The chemical biology of fishes. 2nd ed. New York: Academic Press; 1980.

20. Mills CF, editor. The mineral nutrition of livestock (Underwood EJ. 1981 Ed.) Common Wealth Agricultural Bureaux, 1980; p. 9.

21. Ndome C, Oriakpono O, Ogar A. Proximate composition and nutritional values of some commonly consumed fishes from the Cross River Estuary. Trop Freshwater Biol. 2010; 19(1): 11-8.

22. Omoruyi K, Okpeva O, Abdullahi MM. Effect of oven-drying and smoke-drying on the nutritional quality of snakehead (Parachana $o b$ scura) and upside-down-catfish (Synodontis clarias) in Delta State. FTST Journal. 2017; 2(1): 239-43.

23. Omotosho OE, Oboh G, Iweala EEJ. 2011. Comparative effects of local coagulants on the nutritive value, in-vitro multi enzyme protein digestibility and sensory properties of Wara. Int J Dairy Sci. 2011; 6(1): 58-65.

24. Sadiku SOE, Oladimeji AA. Relationships of proximate composition of Lates niloticus, 
Synodontis schall and Sarotherodon galilaeus from Zaria Dam, Nigeria. BBRC. 1991; 3(1): 29-40.

25. Salihu-Lasisi M, Akpabio CJ, Ogunsola MO. Comparative nutritional studies on fresh and smoked Claras gariepinus (Catfish) and Tilapia niloticus (Tilapia). Euro J Exp Bio. 2013; 3(5): 183-5.

26. Salma EG, Nizar M. Atlantic mackerel amino acids and mineral contents from the Tunisian Middle Eastern coast. IJAPR. 2015; 3(2): 77-83.

27. Shearer KD. Factors affecting the proximate composition of cultured fishes with emphasis on salmonids. Aquaculture. 1994; 119(1): 63-88.

28. Shul'man GE. Life cycle of fish: physiology and biochemistry. 1st ed. New York: Halsted Press; 1974.

29. Soetan KO, Olaiya CO, Oyewole OE. The importance of mineral elements for humans, domestic animals and plants: a review. Afr J Food Sci. 2010; 4(5): 200-22.

30. Womeni HM, Tenyang N, Linder M, Tiencheu B, Villeneuve P, Tchouanguep Mbiapo F. The chemical composition, fatty acid, amino acid profiles and mineral content of six fish species commercialized on the Wouri River Coast in Cameroon. Riv Ital Sostanze Gr. 2014; 91: 129-38.

\section{Ijeoma Patience Oboh, Oluwatosin Adesola Sanni, Nkonyeasua Kingsley Egun}

\section{SYNODONTIS NIGRITA IR TILAPIA MARIAE IŠ JAMIESONO UPĖS (SAPELE, DELTOS VALSTIJA, NIGERIJA) MAISTINĖ SUDĖTIS}

\section{Santrauka}

Žuvies energetinė sudètis yra svarbi gyvūnų ir žmonių mitybai. Tyrimo metu buvo nustatyta Synodontis nigrita ir Tilapia mariae energetinè ir mineralinè sudètis, siekiant išsiaiškinti jų vartojimo naudą. Nuo 2017 m. vasario iki balandžio mènesio upès pakrantèje buvo perkami žuvų pavyzdžiai tyrimui atlikti. Vèliau laboratorijoje buvo atlikti rutininiai kūno matavimai ir biocheminès drègmès, riebalų, pelenų, baltymų, žaliavinių skaidulų, angliavandenių, natrio, kalcio ir magnio kiekio analizès AOAC standartiniais metodais. Energetinès sudèties rodikliai: drègmès kiekis siekè 79,00 \% ir 78,87\%, riebalu vertè $-3,43 \%$ ir 0,67 \%, pelenų kiekis - 6,22 \% ir $6,68 \%$, baltymų vertè - 7,09 \% ir 8,44\%, žaliavinių skaidulų - 0,40\% ir 1,80\%, angliavandenių kiekis - 3,86 \% ir 3,14 \% Synodontis nigrita ir Tilapia mariae atitinkamai. Mineralinè sudètis: natrio koncentracijos vertè siekè 32,90 mg/kg ir 30,20 mg/kg, kalio - 171,70 mg/kg ir 175,60 mg/kg, kalcio - 13,50 $\mathrm{mg} / \mathrm{kg}$ ir 9,20 mg/kg, magnio - 15,00 mg/kg ir 13,40 $\mathrm{mg} / \mathrm{kg}$ Synodontis nigrita ir Tilapia mariae atitinkamai. Tyrimo rezultatai suteikè mokslinių žinių apie komercinių žuvų rūšių mitybinę sudètị.

Raktažodžiai: energetinè sudètis, mineralinè sudètis, Synodontis nigrita, Tilapia mariae, Jamiesono upé 